\title{
Biochemical parameters and antioxidant property of three Salvia L. taxa endemic in Turkey
}

\author{
Parâmetros bioquímicos e propriedade antioxidante de três espécies de Salvia L. \\ endêmicos da Turquia
}

\section{İ. Emre ${ }^{\mathrm{a}}$ (1) and M. Kursat ${ }^{\mathrm{b} *}$ (1)}

aFirat University, Faculty of Education, Department of Basic Education, Elazığ, Turkey

bBitlis Eren University, Faculty of Science and Arts, Department of Biology, Bitlis, Turkey

\begin{abstract}
The aim of the present study was to determine and compare the fatty acids, lipid soluble vitamins, sterols, phenolics, and antioxidant capacities of three endemic Salvia L. taxa (S. euphratica var. Montbret \& Aucher ex Bentham leiocalycina (Rech. Fil.) Hedge, S. euphratica var. Montbret \& Aucher ex Bentham euphratica (Rech. Fil.) Hedge and S. pseudoeuphratica Rech.Fil.) and to evaluate these results systematically. The fatty acid compositions were determined by using gas chromatography, while the lipid soluble vitamins, sterols, and phenolics were determined by using HPLC. Also, the antioxidant capacities of three Salvia taxa were measured in vitro. Palmitic acid was found as major saturated fatty acid while oleic acid, linoleic acid, $\alpha$-linolenic acid, and erucic acid were found as major unsaturated fatty acids in the present study. It was found that $S$. euphratica var. euphratica had lower palmitic acid $(8.94 \pm 0.71 \%)$, total saturated fatty acid (19.16 $\pm 0.15 \%)$, and higher unsaturated fatty acid content $(82.08 \pm$ $0.52 \%)$ than other studied taxa. Furthermore, it was shown that S. euphratica var. euphratica had different 18.3/18:2 (0.36) unsaturated/saturated fatty acid (4.28) ratios. However, this study demonstrated that Salvia taxa had low lipid soluble vitamins, sterol contents. On the other hand, it was shown that Salvia taxa had similar catechin $(509.2 \pm 4.21 \mu \mathrm{g} / \mathrm{g}$ and $552.2 \pm 9.21 \mu \mathrm{g} / \mathrm{g})$ and vanillic acid amounts $(351.2 \pm 2.17 \mu \mathrm{g} / \mathrm{g}$ and $396.8 \pm 4.1 \mu \mathrm{g} / \mathrm{g})$ in this study. And also, it was found that Salvia taxa had high rosmarinic acid content while S. euphratica var. leiocalycina had the highest rosmarinic acid content $(1480 \pm 7.57 \mu \mathrm{g} / \mathrm{g})$. On the other hand, it was shown that the two ferulic acid contents of $S$. euphratica varieties were higher (1175 $\pm / 5.21 \mu \mathrm{gmg}-1740.2 \pm 4.82 \mu \mathrm{g} / \mathrm{mg}$ ) than the ferulic acid content of S. pseudoeuphratica of which was the lowest $(19.2 \pm 0.97 \mu \mathrm{g} / \mathrm{mg})$. The present results suggested that the biochemical results guided the morphological studies, and Salvia taxa have a potent antioxidant capacity.
\end{abstract}

Keywords: antioxidant property, biochemical parameters, GC-MS, HPLC, Lamiaceae.

\begin{abstract}
Resumo
O objetivo do presente estudo foi determinar e comparar os ácidos graxos, vitaminas lipossolúveis, esteróis, fenóis e capacidades antioxidantes de três espécies endêmicas de Salvia L. (S. euphratica var. Montbret \& Aucher ex Bentham leiocalycina (Rech. Fil.) Hedge, S. euphratica var. Montbret \& Aucher ex Bentham euphratica (Rech. Fil.) Hedge e S. pseudoeuphratica Rech.Fil.) e avaliar esses resultados sistematicamente. As composições de ácidos graxos foram determinadas por cromatografia gasosa, enquanto as vitaminas lipossolúveis, esteróis e fenóis foram determinadas por HPLC. Além disso, as capacidades antioxidantes das três espécies de Salvia foram medidas in vitro. $\mathrm{O}$ ácido palmítico foi encontrado como ácido graxo saturado principal, enquanto o ácido oleico, ácido linoleico, ácido $\alpha$-linolênico e ácido erúcico foram encontrados como principais ácidos graxos insaturados no presente estudo. Verificou-se que S. euphratica var. euphratica tem menor teor de ácido palmítico ( $8.94 \pm 0.71 \%$ ) e ácido graxo saturado total (19.16 $\pm 0.15 \%)$ e maior teor de ácidos graxos insaturados $(82.08 \pm 0.52 \%)$ do que as outras espécies estudadas. Além disso, foi demonstrado que a $S$. euphratica var. euphratica apresentou diferentes proporções 18:3/18:2 (0.36) de ácidos graxos insaturados/saturados (4.28). No entanto, este estudo demonstrou que o gênero Salvia tinha baixo teor de vitaminas lipossolúveis e baixo conteúdo de esteróis. Por outro lado, foi demonstrado que as espécies do gênero Salvia contém quantidades de catequinas (509.2 $\pm 4,21 \mu \mathrm{g} / \mathrm{mg}-552.2 \pm 9.21$ $\mu \mathrm{g} / \mathrm{mg}$ ) e ácido vanílico semelhantes (351.2 $\pm 2.17 \mu \mathrm{g} / \mathrm{mg} 396,8 \pm 4,1 \mu \mathrm{g} / \mathrm{mg}$ ). Descobriu-se também que o gênero Salvia tinha alto conteúdo de ácido rosmarínico enquanto a espécie $S$. euphratica var. leiocalycina apresentou o maior teor desse ácido $(1.480 \pm 7.57 \mu \mathrm{g} / \mathrm{g}$ ). Por outro lado, foi demonstrado que os teores de ácido ferúlico da espécie $S$. eupratica foram maiores $(1.175 \pm 5.21 \mu \mathrm{g} / \mathrm{mg}-1740.2 \pm 4.82 \mu \mathrm{g} / \mathrm{mg})$ do que o conteúdo de ácido ferúlico da espécie S. pseudoeuphratica dos quais foi o mais baixo $(19.2 \pm 0.97 \mu \mathrm{g} / \mathrm{mg})$. Os resultados atuais sugerem que os resultados bioquímicos orientaram os estudos morfológicos e as espécies de Salvia têm uma potente capacidade antioxidante.
\end{abstract}

Palavras-chave: propriedade antioxidante, parâmetros bioquímicos, GC-MS, HPLC, Lamiaceae.

*e-mail: botanikkursat@gmail.com

Received: June 13, 2020 - Accepted: November 16, 2020

This is an Open Access article distributed under the terms of the Creative Commons Attribution License, which permits unrestricted use, distribution, and reproduction in any medium, provided the original work is properly cited. 


\section{Introduction}

The Lamiaceae, is one of the largest families in the plant kingdom, and includes more than 240 genera that are aromatic (Sharafzadeh and Zare, 2011). Sage, Thymus, Rosemary, Marjoram and Basil are some of the popular aromatic plants belonging to Lamiaceae growing in both the Mediterranean and Asia (Naghibi et al., 2005; Hossain et al., 2010; Khled Khoudja et al., 2014). Sage (Salvia L.), from the subfamily Nepetoideae of the Mentha tribe in the Lamiaceae, is spread throughout different regions of the world and has more than 1000 taxa (Kalaycioğlu et al., 2018). Some species of Salvia L. have the significant pharmaceutical properties and have been used in traditional medicine since ancient times (Asadi et al., 2010; Loizzo et al., 2010). Also, the members of Salvia L. are consumed as herbal tea and also used in cosmetics, flavouring agents, and perfumery industries (Loizzo et al., 2010; Akbulut and Bayramoglu, 2013). The genus is represented by 100 taxa of which 57 are endemic, with Anatolia being a remarkable center for the genus (Celep et al., 2015; Bardakci et al., 2019).

The studies demonstrated that Salvia L. species have antidiabetic, antiviral, antioxidant, anticancer, and anti-inflammatory effects due to possessing the most important biological active compounds including sterols, terpenoids, essential oils, and plyphenolics (Asadi et al., 2010; Ben Farhat et al., 2015a; El Euch et al., 2019). There are several studies related to determining the biochemical characteristics and antioxidant capacity of different Salvia species (Tepe et al., 2006; Kelen and Tepe, 2008; Tosun et al., 2009; Gezek et al., 2019). However, to the best of our knowledge, there is no biochemical and antioxidant report concerning three endemic taxa ( $S$. euphratica var. leiocalycina, S. euphratica var. euphratica and S. pseudoeuphratica). Therefore, the aim of this study is to determine and compare the fatty acid compositions, lipidsoluble vitamins, sterols, flavonoids, phenolic acids, radical scavenging activities, and total phenolics of S. euphratica var. Montbret \& Aucher ex Bentham leiocalycina (Rech. Fil.) Hedge, S. euphratica var. Montbret \& Aucher ex Bentham euphratica (Rech. Fil.) Hedge and S. pseudoeuphratica Rech. Fil. Another purpose is to compare biochemical results with morphological results. Systematically, Hedge (1982a, b) changed the taxonomic position of S. euphratica after it had been identified by Bentham (1836) from Turkey (Dizkirici et al., 2015). However, S. leiocalycina has been evaluated under a variety of the S. euphratica based on the results of morphological and ecological studies, and in the most recent studies, S. pseudoeuphratica is accepted as being a different species by Kahraman et al. (2010).

\section{Material and Methods}

\subsection{Chemical agents}

All the chemicals were provided by Sigma-Aldrich.

\subsection{Plant materials}

S. euphratica var. Montbret \& Aucher ex Bentham leiocalycina (Rech. Fil.) Hedge (B7, Baskil district, marble factory around, railway near, $1330 \mathrm{~m}, 38^{\circ} 34^{\prime} 56^{\circ} \mathrm{N}, 38^{\circ}$ $50^{\prime} 23^{\circ} \mathrm{E}, \mathrm{M}$. KURŞAT 1610), S. euphratica var. Montbret \& Aucher ex Bentham euphratica (Rech. Fil.) Hedge (B7, Elazig-Malatya road, Komurhan district, $755 \mathrm{~m}, 38^{\circ} 27^{\prime} 10^{\circ} \mathrm{N}$, $3848^{\prime} 28^{\circ} \mathrm{E}$, M. KURŞAT 1611) and S. pseudoeuphratica Rech. Fil. (B7, Elazı ğ, Keban-Elazı ğ road, $3^{\text {rd }}-4^{\text {th }} \mathrm{km}, 900 \mathrm{~m}, 38^{\circ}$ $44^{\prime} 46^{\circ} \mathrm{N}, 38^{\circ} 47^{\prime} 59^{\circ} \mathrm{E}, \mathrm{M}$. KURŞAT 1622) were collected that grow as native plants in Turkey in 2011, which were deposited in FUH (Firat University Herbarium). The identification of collected materials were done by Murat KURSAT. After the collection and identification, the plant materials were immediately extracted, and HPLC and GC-MS analyses were completed.

\subsection{Extraction of plant materials}

\subsubsection{The analysis of fatty acid, lipid soluble, vitamins and sterol}

After collection, each plant material was dried at room temperature, grounded and then, extracted with isopropanol/hexane (2:3) as suggested by Hara and Radin, (1978). The lipid samples were centrifuged at $10.000 \mathrm{~g}$, for $5 \mathrm{~min}$. The solvent was evaporated by using a rotary evaporator at $40{ }^{\circ} \mathrm{C}$, and the samples were kept at $-25^{\circ} \mathrm{C}$.

\subsubsection{Preparation of fatty acid methyl esters}

In order to determine fatty acids analyses in lipids using gas chromatography, they must be converted into methyl esters derivatives. The FAME analysis was conducted based on the method by Christie (1990). Fatty Acid Methyl Esters (FAME) are produced from vegetable oils by transesterification. In this process, a glyceride reacts with an alcohol in the presence of a catalyst, forming a mixture of fatty acids esters and an alcohol (Schuchardta et al., 1998). Hexane was used to extract FAME. To prepare methyl ester, the lipid extract in the hexane/isopropanol phase $(3: 2, \mathrm{v} / \mathrm{v})$ was taken into $30 \mathrm{~mL}$ non-leakage test tubes. $5 \mathrm{~mL}$ of $2 \%$ methanolic sulfuric acid was added to the extraction and mixed using a vortex. This mixture was left to be methylated in a $50{ }^{\circ} \mathrm{C}$ oven for 15 hours, and then the tubes were cooled to room temperature and mixed well by adding $5 \mathrm{~mL}$ of $5 \% \mathrm{NaCl}$. The fatty acid methyl esters formed were extracted with $5 \mathrm{~mL}$ hexane, and the hexane phase was taken, and treated with $5 \mathrm{~mL}$ of $2 \% \mathrm{KHCO}_{3}$. The extracts were left for four hours to separate phases and the solvent in the mixture including the methyl esters was evaporated at $45^{\circ} \mathrm{C}$ and under nitrogen flow. Then, the samples were dissolved with $1 \mathrm{~mL}$ of hexane and taken into $2 \mathrm{~mL}$ otosampler vials to analyze with gas chromatography (Bahsi, 2008).

\subsubsection{Fatty acid methyl esters in the gas chromatography}

After obtaining the methyl esters from fatty acids, they were analyzed by SHIMADZU (Kyoto, Japan) GC 17 Ver. 3 Gas Chromatography. GC Capillary Column Permabond CW 20 M-DEG ID: $0.25 \mathrm{~mm}$, film thickness: $0.25 \mu \mathrm{m}$ length: 25 (Macherey-Nagel ${ }^{\circledR}$ Germany) was used for the analysis. The column temperature was adjusted between 
$120-220^{\circ} \mathrm{C}$, the injection temperature was kept at $240{ }^{\circ} \mathrm{C}$, and the detector temperature was at $280^{\circ} \mathrm{C}$ during analysis. Prior to the analysis of the fatty acid methyl esters, the retention times of each fatty acid were determined by injecting mixtures of standard fatty acid methyl esters, and an analysis of fatty acid methyl esters mixtures was performed. Each of the total fatty acids were calculated as a percentage amount. Results were calculated by using the GC Solution 2.3 program.

\subsubsection{Chromatographic analysis and quantification of lipid soluble vitamins and sterols}

The Shimadzu SPD UV detector VP series HPLC apparatus equipped with a DAD detector was used to determine the sterols (ergosterol, sitosterol and beta-sitosterol) and to perform a lipid-soluble vitamins analysis according to the Sánchez-Machado et al. (2002)' method. The samples were homogenized in a $2 \mathrm{~mL}$ acetonitrile/methanol $(3 / 1, \mathrm{v} / \mathrm{v})$ mixture for one minute. The extracts were centrifuged at $6000 \mathrm{~g}$ for $10 \mathrm{~min}$. at $4{ }^{\circ} \mathrm{C}$, and $1 \mathrm{~mL}$ supernatant was taken into vials and analyzed on HPLC. The extracts were treated with acetonitrile/methanol $(75 / 25 \mathrm{v} / \mathrm{v})$. The flow rate of the mobile phase was determined to be $1 \mathrm{~mL} / \mathrm{min}$., and the temperature of the analytical column was kept at $40{ }^{\circ} \mathrm{C}$. Supelcosil LC $18 \mathrm{DB}(250 \times 4.6 \mathrm{~mm}, 5 \mu \mathrm{m}$; Sigma, USA) colon was used as a reverse phase column. Class Vp 61 Software supplied by the Shimadzu Corporation was used to determine the amount of each compound in the samples, and results were given as $\mu \mathrm{g} / \mathrm{mL}$. The detection of retinol and retinol acetate were done at $320 \mathrm{~nm}$, while $\alpha$-tocopherol, vitamin D, a-tocopherol, $\alpha$-tocopherol acetate was detected at $215 \mathrm{~nm}$, and phytosterols were detected at $202 \mathrm{~nm}$, and vitamin K1 and K2 were detected at $265 \mathrm{~nm}$ (López-Cervantes et al., 2006). Class Vp 6.1 software was used to calculate the amounts in the study.

\subsection{The extraction procedure}

$2 \mathrm{~g}$ seed was ground and treated with $5 \mathrm{~mL} \mathrm{80 \%}$ methanol to homogenization for flavonoids and phenolic acids analyses. The homogenization was performed at $5000 \mathrm{rpm}$ at $+4^{\circ} \mathrm{C}$. And rotary evaporation was used to obtain a supernatant. Lastly, extracts were suspended by $2 \mathrm{~mL}$ dimethyl sulphoxide (DMSO) (Kursat et al., 2011).

\subsubsection{Chromatographic conditions for phenolics}

The flavonoids and phenolic acids were determined based on the method by Zu et al. (2006). Two g of plant materials were homogenized with a $5 \mathrm{~mL} 80 \%$ methanol solution, and extracts were centrifuged at $5000 \mathrm{rpm}$ at $+4{ }^{\circ} \mathrm{C}$, and dimethyl sulphoxide (DMSO) was used to supply a stock solution. The column was a PREVAIL C18 reversedphase column ( $15 \times 4.6 \mathrm{~mm}, 5 \mu \mathrm{m}$, USA), and the mobile phase was methanol/water/acetonitrile $(46 / 46 / 8, \mathrm{v} / \mathrm{v} / \mathrm{v})$ comprised of $1.0 \%$ acetic acid in the chromatographic analysis (Zu et al., 2006). The flow ratio was $1.05 \mathrm{~mL} / \mathrm{min}$., and the injection volume was $10 \mu \mathrm{L}$. The chromatographic peaks were confirmed by determining the retention times with those of the standards. Rutin, myricetin, morin, quercetin, and vanillic acid at $254 \mathrm{~nm}$; kaempferol at $264 \mathrm{~nm}$; catechin, naringin and cinnamic acid at $280 \mathrm{~nm}$; naringenin at $285 \mathrm{~nm}$; resveratrol at $306 \mathrm{~nm}$; and caffeic acid, ferulic acid and rosmarinic acid at $330 \mathrm{~nm}$ were determined by DAD following the RP-HPLC (Shimadzu SPD UV detector VP series HPLC). The chromatographic studies were done at $25{ }^{\circ} \mathrm{C}$.

\subsection{Antioxidant activity}

\subsubsection{DPPH Radical scavenging capacity}

The DPPH radical scavenging capacity was measured based on the method by Liyana-Pathirana and Shahidi (2005). $4.0 \mathrm{~mL}$ DPPH solution was mixed with 25, 50, 100,150 , and $250 \mu \mathrm{L}$ of extract. The complex was kept in darkness for 30 minutes at room temperature (LiyanaPathirana and Shahidi, 2005). The absorbances were measured at $517 \mathrm{~nm}$, using Shimadzu UVmini-1240 (UV-VIS Spectrophometer). Quercetin $(1 \mu \mathrm{M})$ was used as reference standard. The results were determined by using Formula 1 :

$$
\begin{aligned}
& \text { DPPH radical scavenging capacity }(\%)= \\
& [(\text { Abs_control }- \text { Abs_sample })] /(\text { Abs control })] \times 100
\end{aligned}
$$

Abs_control is the absorbance of the DPPH radical + methanol; Abs_sample is the absorbance of DPPH radical + sample extract/standard.

\subsubsection{ABTS assay}

The 2,2-azinobis-(3-ethylbenzothiazoline-6-sulfonic acid) diammonium salt (ABTS) method was used in accordance to Re et al. (1999). The ABTS (7 mM) was mixed with $2.45 \mathrm{mM}$ potassium persulphate and used to obtain ABTS radical cation $\left(\right.$ ABTS $\left.^{*}\right)$. The solution was stored for $12-16 \mathrm{~h}$ at room temperature. The (ABTS•+) solution was dissolved with water to measure an absorbance of $0.700 \pm 0.020$ at $734 \mathrm{~nm}$. The $3 \mathrm{~mL}$ ABTS solution was treated with 25, $50,100,150$ and $250 \mu \mathrm{L}$ extracts, and the absorption was detected at $6 \mathrm{~min}$. The absorbance of the control $(3.0 \mathrm{~mL}$ $\left(\right.$ ABTS $^{*+}$ ) solution with $30 \mathrm{~L}$ water) was written as Acontrol (Skotti et al., 2014) (Formula 2).

$$
\begin{aligned}
& \text { ABTS radical cation scavenging capacity }(\%)= \\
& [(\text { Abs_control }- \text { Abs_sample })] /(\text { Abs_control })] \times 100
\end{aligned}
$$

\subsubsection{Metal chelating activity}

The chelating capacity of the plant materials were assessed based on the Dinis et al.'s (1994) method. According to this method, $50 \mu \mathrm{L}$ of $2 \mathrm{mM} \mathrm{FeCl}_{2}$ was added to several concentrations including 50,100,250, and $500 \mu \mathrm{g} / \mathrm{mL}$ of extracts. $0,2 \mathrm{~mL}$ ferrozine was added to the mixture to start the reaction. The solution was kept at room temperature for 10 minutes after the solution was firmLy mixed. $562 \mathrm{~nm}$ was used as absorbance (Dinis et al., 1994). The percentage inhibiting of the ferrozine- $\mathrm{Fe}^{2+}$ complex was found as the following Formula 3:

$$
\begin{aligned}
& \text { The Ferrous ion chelating activity }(\%)= \\
& {[1-(\mathrm{As} / \mathrm{Ac})] \times 100}
\end{aligned}
$$

where $A_{c}$ is the absorbance of the control, and As is the absorbance of the extract/ standard (KizilpinarTemizer et al., 2017). Positive control is $\mathrm{Na}_{2}$ EDTA. 


\subsubsection{Determination of antioxidant activity by MDA/ TBARS formation}

The antioxidant activity of materials was done using the method proposed by Shimoi et al. (1994). The extracts were prepared by using DMSO (dimethyl sulfoxide). Oleic acid (3.35 mM), linoleic acid (9.01 mM), linolenic acid $(2.30 \mathrm{mM})$ dissolving in the DMSO, $\mathrm{Fe}^{2+}\left(\mathrm{FeCl}_{2} \cdot 2 \mathrm{H}_{2} \mathrm{O}\right)$ and hydrogen peroxide are used in the experiment. The Control, Fenton reagent group, and the group of sage extracts were formed. The control group contained $0.5 \mathrm{~mL}$ of fatty acid and a buffer solution ( $0.2 \%$ Tween 20/0.05 M Tris HCl/0.15 M $\mathrm{KCl}, \mathrm{pH}=7.4$ ), whilst the fenton group contained $0.5 \mathrm{~mL}$ of fatty acid, a buffer solution, $\mathrm{FeCl}_{2} \cdot 2 \mathrm{H}_{2} \mathrm{O}(50 \mu \mathrm{M})$, and hydrogen peroxide $(0.01 \mathrm{mM})$. Also, the sample extracts contained $0.5 \mathrm{~mL}$ of fatty acid, a buffer, $\mathrm{FeCl}_{2}(50 \mu \mathrm{M})$, hydrogen peroxide $(0.01 \mathrm{mM})$, and $0.25 \mathrm{~mL}$ sage extract. All the groups were stored at $37^{\circ} \mathrm{C}$ for $24 \mathrm{~h}$ for incubation by adding $0.1 \mathrm{~mL}$ of a $4 \%(\mathrm{w} / \mathrm{v})$ BHT to protect the greater oxidation. After that, $1 \mathrm{~mL}$ was taken from the samples in all the three groups and $1 \mathrm{~mL}$ of $0.6 \%$ TBA was added to the reaction mixture and samples incubated at $90^{\circ} \mathrm{C}$ for $30 \mathrm{~min}$. Finally, $4 \mathrm{~mL}$ butan-1-ol was added to the tubes, mixed, and centrifuged at $4250 \mathrm{rpm}$ for $10 \mathrm{~min}$. The absorbance of the supernatant was determined at $532 \mathrm{~nm}$ using a spectrophotometer Shimadzu UV mini-1240. MDA standard curves were formed by 1,1,3,3-tetramethoxypropane, and thiobarbituric acid-reactive substances (TBARS) were expressed as mg MDA/kg dry matter (Keser et al., 2014).

\section{Results and Discussion}

This study showed that the main saturated fatty acids in Salvia taxa were palmitic acid (16:0) and stearic acid (18:0) (Table1). The palmitic acid contents of the studied Salvia taxa were between $8.94 \pm 0.71 \%$ (S. euphratica var. euphratica) and $32.57 \pm 1.29 \%$ (S. euphratica var. leiocalycina). The stearic acid was the second major saturated fatty acid in the studied Salvia taxa (3.04 $\pm 0.22 \%-7.89 \pm 0.86 \%)$. The other saturated fatty acids were myristic acid (14:0) and arachidic acid (20:0). Caprylic acid (8:0), capric acid (10:0), undecylic acid (11:0), behenic acid (22:0) and lignoceric acid (24:0) were either absent or in low amounts (Table 1). Azcan et al. (2004) showed that palmitic acid and stearic acid were major saturated fatty acids in Salvia. Also, different studies demonstrated that Salvia species have palmitic acid and stearic acid as saturated fatty acids (Bagci et al., 2004; Kilic et al., 2005; Alipour-Gough and Asgarpanah, 2015; Moazzami Farida et al., 2016). However, the results of Habibvash et al. (2007) conflict with the present study because they found that palmitic acid and stearic acid content of Salvia taxa were lower than in this study (Habibvash et al., 2007). Moreover, they determined that some Salvia taxa had a high arachidic acid content (14.82-26.91\%) (Habibvash et al., 2007). Also, Delange et al. (2012) determined that Salvia had a higher stearic acid and arachidic acid content than palmitic acid content. Furthermore, Bakoglu et al. (2016) determined that Salvia had higher stearic acid (2.88-22.54\%) and arachidic acid (4.32-13.9\%) content than the present study. Furthermore, Kilic (2018) found that the stearic acid (36.33\%) content of S. euphratica var. leiocalycina were higher than in the present study while he found that it has a similar palmitic acid content with current study (Kilic, 2018). On the other hand, $\alpha$-linolenic acid (18:3 n3), linoleic acid (18:2 n6), oleic acid (18:1 n9) were determined as a major unsaturated fatty acids in this study (Table 1). S. pseudoeuphratica had the highest $\alpha$-linolenic acid ( $29.45 \pm 1.32 \%)$, is $\omega$ - 3 fatty acid, while $S$. euphratica var. euphratica had the lowest $\alpha$-linolenic acid $(11.53 \pm 1.19 \%)$ in this study. The current study also showed that the $\alpha$-linolenic acid content of S. euphratica var. leiocalycina was $16.23 \pm 1.01 \%$. Also, it was found that S. euphratica var. euphratica had the highest linoleic acid content (31.58 $\pm 1.16 \%$ ), $\omega-6$ fatty acids, and its $\omega-6$ fatty acid content was different from S. euphratica var. leiocalycina $(12.06 \pm 0.98 \%)$. Also, it was found that the linoleic acid content of S. pseudoeuphratica was $7.48 \pm 0.63 \%$. Essential fatty acids (EFAs) are polyunsaturated fatty acids and cannot be synthesized by humans but must be taken from food, and they are divided into two groups, omega- 6 and omega-3 (Turan et al., 2013). Similarly, previous studies showed that linoleic acid, oleic acid and linolenic acid were primary unsaturated fatty acids in Salvia (Azcan et al., 2004; Kilic et al., 2005; Alipour-Gough and Asgarpanah, 2015; Ben Farhat et al., 2015b). Furthermore, it was indicated that an 18:3/18:2 ratio should be used as a taxonomic tool in Lamiaceae (Azcan et al., 2004; Goren et al., 2006) and it was found that the 18:3/18:2 ratio of S. euphratica var. euphratica (0.36) was different from $S$. euphratica var. leiocalycina (1.34) and S. pseudoeuphratica (3.93) in the present study. Besides, S. euphratica var. leiocalycina has higher oleic acid content $(11.82 \pm 1.24 \%)$ than S. euphratica var. euphratica $(9.07 \pm 1.13 \%)$ and S. pseudoeuphratica $(4.71 \pm$ $0.49 \%)$. Palmitoleic acid (16:1 n7) and erucic acid (22:1) were the other dominant unsaturated fatty acids in the three Salvia taxa. S. euphratica var. euphratica had higher erucic acid $(22: 1 ; 20.13 \pm 1.47 \%)$ than $S$. euphratica var. leioclaycina $(2.42 \pm 0.3 \%)$ and S. pseudoeuphratica $(5.87 \pm 0.59 \%)$, but it had the lowest palmitoleic acid (16:1 n7) content in the study. Moreover, myristoleic acid (14:1), pentadecanoic acid (15:1), heptadecanoic acid (17:1), eicosadienoic acid (20:2 n6) and eicosapentaenoic (20:5 n3) contents were absent or low in the present study. Also, this study showed that the ratio of unsaturated fatty acids (61.38 \pm $0.67 \%-82.08 \pm 0.52 \%$ ) were more than the ratio of saturated fatty acids and it was determined that the proportion of unsaturated fatty acids were larger than the saturated fatty acids in Lamiaceae (Azcan et al., 2004). And it was found that the ratio of unsaturated fatty acid to saturated fatty acid (U/S) of S. euphratica var. euphratica (4.28) was different from S. euphratica var. leiocalycina (1.32) and $S$. pseudoeuphratica (1.67) (Table 1).

The current study showed the studied three Salvia taxa low lipid soluble vitamins and sterol content (Table 1). It was determined that $S$. euphratica var. leiocalycina and S. pseudoeuphratica had higher $\alpha$-tocopherol (25.05 \pm $1.14 \mu \mathrm{g} / \mathrm{g}, 19.5 \pm 0.97 \mu \mathrm{g} / \mathrm{g}$, respectively) than S. euphratica var. euphratica $(6.14 \pm 0.37 \mu \mathrm{g} / \mathrm{g})$. Also, it was found that K1 vitamin contents of three Salvia taxa were determined as $4.05 \pm 0.15 \mu \mathrm{g} / \mathrm{g}$ (S. euphratica var. leiocalycina), $7.87 \pm 0.14 \mu \mathrm{g} / \mathrm{g}$ (S. euphratica var. euphratica) and $2.7 \pm$ $0.2 \mu \mathrm{g} / \mathrm{g}$ (S. pseudoeuphratica). Similarly, Sari et al. (2009) 
Table 1: Fatty acid, lipid soluble vitamins, sterols content $(\mu \mathrm{g} / \mathrm{mg})$ in polar extracts from three Turkish Salvia taxa

\begin{tabular}{|c|c|c|c|}
\hline Chemical composition & $\begin{array}{l}\text { S. euphratica var. } \\
\text { leiocalycina }\end{array}$ & $\begin{array}{l}\text { S. euphratica var. } \\
\text { euphratica }\end{array}$ & S. pseudoeuphratica \\
\hline \multicolumn{4}{|l|}{ Saturated fatty acids* } \\
\hline$(8: 0)$ & - & $0.39 \pm 0.01$ & - \\
\hline 10:0 & - & - & $1.01 \pm 0.45$ \\
\hline 11:0 & - & $0.42 \pm 0.01$ & - \\
\hline 14:0 & $1.37 \pm 0.14$ & $0.69 \pm 0.01$ & $1.25 \pm 0.27$ \\
\hline $16: 0$ & $32.57 \pm 1.29$ & $8.94 \pm 0.71$ & $24.16 \pm 1.42$ \\
\hline 18:0 & $7.12 \pm 0.57$ & $3.04 \pm 0.22$ & $7.89 \pm 0.86$ \\
\hline 20:0 & $1.7 \pm 0.32$ & $1.07 \pm 0.1$ & $2.24 \pm 0.27$ \\
\hline 22:0 & - & $2.00 \pm 0.11$ & \\
\hline 24:0 & - & $2.61 \pm 0.1$ & \\
\hline Total & $42.76 \pm 0.58$ & $19,16 \pm 0.15$ & $36.55 \pm 0.65$ \\
\hline \multicolumn{4}{|l|}{ Unsaturated fatty acids* } \\
\hline 14:1 & $1.3 \pm 0.1$ & - & - \\
\hline 15:1 & - & $1.26 \pm 0.1$ & $4.28 \pm 0.37$ \\
\hline 16:1 n7 & $12.9 \pm 1.21$ & $2.9 \pm 0.1$ & $9.59 \pm 0.65$ \\
\hline $17: 1$ & - & $2.27 \pm 0.12$ & - \\
\hline 18:1 n9 & $11.82 \pm 1.24$ & $9.07 \pm 1.13$ & $4.71 \pm 0.49$ \\
\hline $18: 2 \mathrm{n} 6$ & $12.06 \pm 0.98$ & $31.58 \pm 1.16$ & $7.48 \pm 0.63$ \\
\hline $18: 3$ n3 & $16.23 \pm 1.01$ & $11.53 \pm 1.19$ & $29.45 \pm 1.32$ \\
\hline $18: 3$ n6 & - & $0.7 \pm 0.01$ & - \\
\hline $20: 2 n 6$ & - & $0.39 \pm 0.1$ & - \\
\hline $20: 5$ n3 & - & $1.67 \pm 0.24$ & \\
\hline 22:1 & $2.42 \pm 0.3$ & $20.13 \pm 1.47$ & $5.87 \pm 0.59$ \\
\hline Total & $56.73 \pm 0.8$ & $82.08 \pm 0.52$ & $61.38 \pm 0.67$ \\
\hline 18:3/18:2 & 1.34 & 0.36 & 3.93 \\
\hline Unsaturated/Saturated(U/S) & 1.32 & 4.28 & 1.67 \\
\hline \multicolumn{4}{|l|}{$\begin{array}{l}\text { Lipid soluble vitamin and } \\
\text { sterol }^{* *}\end{array}$} \\
\hline K1 & $4.05 \pm 0.15$ & $7.87 \pm 0.14$ & $2.7 \pm 0.2$ \\
\hline K2 & $0.25 \pm 0.01$ & $0.68 \pm 0.01$ & $0.65 \pm 0.01$ \\
\hline R-tocopherol & $0.22 \pm 0.01$ & $1.04 \pm 0.01$ & $0.2 \pm 0.01$ \\
\hline D2 & $1.2 \pm 0.12$ & $1.34 \pm 0.01$ & $1.5 \pm 0.35$ \\
\hline D3 & $0.32 \pm 0.01$ & $0.35 \pm 0.01$ & $1.15 \pm 0.32$ \\
\hline a-tocopherol & $25.05 \pm 1.14$ & $6.14 \pm 0.37$ & $19.5 \pm 0.97$ \\
\hline Retinol & - & - & $0.25 \pm 0.01$ \\
\hline Retinol-acetate & $1.1 \pm 0.1$ & $2.1 \pm 0.32$ & $1.35 \pm 0.14$ \\
\hline Stigmasterol & $44.21 \pm 1.22$ & $80.14 \pm 1.34$ & $66.4 \pm 1.27$ \\
\hline B-sitosterol & $42.45 \pm 1.41$ & $102.17 \pm 1.24$ & $87.15 \pm 1.53$ \\
\hline
\end{tabular}

*B Gas chromatography. ${ }^{* *}$ By High pressure liquid chromatography.

found that Salvia taxa had a low lipid soluble vitamin content and they determined that D2, D3, $\alpha$-tocopherol acetate and $\mathrm{K} 1$ content of $S$. euphratica were $15.0 \mu \mathrm{g} / \mathrm{g}$, $18.0 \mu \mathrm{g} / \mathrm{g}, 7.4 \mu \mathrm{g} / \mathrm{g}$ and $7.8 \mu \mathrm{g} / \mathrm{g}$, respectively. Sterols are structural elements of the cell membrane and play a significant role in the regulation of membrane fluidity and permeability (Trautwein and Demonty, 2007). Also, they are used as therapeutic agents to reduce plasma cholesterol concentration (St-Onge and Foo, 2003). This study determined that the $ß$-sitosterol content of the studied Salvia taxa were between $42.45 \pm 1.41 \mu \mathrm{g} / \mathrm{g}$ (S. euphratica var. leiocalycina) and $102.17 \pm 1.24 \mu \mathrm{g} / \mathrm{g}$ (S. euphratica var. euphratica) and their stigmasterol content were between $44.21 \pm 1.22 \mu \mathrm{g} / \mathrm{g}$ (S. euphratica 
var. leiocalycina) and $80.14 \pm 1.34 \mu \mathrm{g} / \mathrm{g}$ (S. euphratica var. euphratica; Table 1 ).

Recent studies have shown that phenolic compounds from medicinal plants are important because of the various benefits, especially their antioxidant effect, and these studies supported significant steps for the discovery of new drugs (Tungmunnithum et al., 2018; Najjaa et al., 2020). It was found that Salvia taxa had high catechin content (509.2 \pm $1.21 \mu \mathrm{g} / \mathrm{mg}-552.2 \pm 9.21 \mu \mathrm{g} / \mathrm{mg}$; Table 2 ) in the present study. It was suggested that catechin has free radical scavenging effects, inhibit the extracellular matrix degradation caused by UV, and have anti allergenic and anti-inflammatory effects (Bae et al., 2020). Also, catechin plays a significant role against cancer, diabetes, obesity, cardiovascular diseases, infections, and neurodegenerative diseases (Isemura, 2019).

Also, it was determined that S. euphratica var. euphratica and S. pseudoeuphratica had high rutin content (328.4 \pm $4.27 \mu \mathrm{g} / \mathrm{mg}$ and $308.6 \pm 5.01 \mu \mathrm{g} / \mathrm{mg}$, respectively). However, it was seen that the rutin amount of $S$. euphratica var. leiocalycina was the lowest $(32 \pm 1.12 \mu \mathrm{g} / \mathrm{mg})$. On the other hand, it was showed that the naringenin amount of $S$. euphratica var. leiocalycina was higher $(92.8 \pm 2.17 \mu \mathrm{g} / \mathrm{mg})$ than the other studied taxa (Table 2). The myricetin, morin, quercetin, kaempferol, and naringin amounts of the studied taxa were either absent or in low amounts in the present study (Table 2). In a study conducted by Kivrak et al. (2019), it was reported that Salvia had kaempferol, naringenin, rutin, vanillic acid, caffeic acid, and ferulic acid content. However, they found that Salvia did not have myricetin, resveratrol and quercetin (Kivrak et al., 2019). Also, Zengin et al. (2018) reported that in Salvia species including S. euphratica var. leiocalycina possess rutin, apigenin, kaempferol, luteolin, protocatechuic acid, rosmarinic acid, caffeic acid, and 3- O-caffeoylquinic acid. Conversely, the present study showed that the vanillic acid contents of Salvia taxa were between $351.2 \pm 2.17 \mu \mathrm{g} / \mathrm{mg}$ and $396.8 \pm 4.1 \mu \mathrm{g} / \mathrm{mg}$. The results obtained from this study found that $S$. euphratica var. leiocalycina and S. euphratica var. euphratica had a higher rosmarinic acid content (1480 $\pm 7.57 \mu \mathrm{g} / \mathrm{mg}, 989 \pm$ $4.92 \mu \mathrm{g} / \mathrm{mg}$, respectively) than S. pseudoeuphratica (546.2 \pm $7.61 \mu \mathrm{g} / \mathrm{mg}$; Table 2). It was reported that rosmarinic acid is the most prominent compound in Salvia species, and it is chiefly responsible for the antioxidant activity in Salvia (Lu and Yeap, 2002). Meanwhile, it was reported that vanillic acid has pharmacological effects against cancer, cardiovascular disease, inflammation, oxidative stress, and is used as a food additive (Dandekar and Wasewar, 2020). In addition, two $S$. euphratica taxa had the highest ferulic acid content ( $1740.2 \pm 4.82 \mu \mathrm{g} / \mathrm{mg}$ and $1175 \pm 5.21 \mu \mathrm{g} / \mathrm{mg}$ ) whereas it was found that $S$. pseudoeuphratica had the lowest ferulic acid (19.2 $\pm 0.97 \mu \mathrm{g} / \mathrm{mg})$. It was reported that ferulic acid contributed to the reduction in oxidative stress in the ß-cells and stimulated insulin secretion, and it has anticarcinogenic activity by stimulating cytoprotective enzymes against free radical damage (Kumar and Pruthi, 2014). However, S. pseudoeuphratica had higher caffeic acid content $(153.2 \pm 2.13 \mu \mathrm{g} / \mathrm{mg})$ than $S$. euphratica taxa, while the cinnamic acid content of the studied Salvia taxa had the lowest or had trace amounts (Table 2). A study conducted by Yumrutas et al. (2012), found that rosmarinic acid and caffeic acid were dominant phenolics in two varieties of S. euphratica, whereas the present study showed that S. euphratica var. leiocalycina does not have caffeic acid. Adimcilar et al. (2019) determined that the rosmarinic acid content of S. euphratica var. leiocalycina was $9.81 \pm 0.23 \mathrm{mg} / \mathrm{g}$. Similarly, some studies showed that Salvia taxa had high rosmarinic acid content (Tepe, 2008; Erdogan-Orhan et al., 2012; Kocak et al., 2016).

Table 2: Flavonoids and phenolic acid content $(\mu \mathrm{g} / \mathrm{mg})$ in polar extracts from three Turkish Salvia taxa

\begin{tabular}{cccc}
\hline Compound & $\begin{array}{c}\text { S. euphratica var. } \\
\text { leiocalycina }\end{array}$ & $\begin{array}{c}\text { S. euphratica var. } \\
\text { euphratica }\end{array}$ & S. pseudoeuphratica \\
\hline Flavonoids* & $32 \pm 1.12$ & $328.4 \pm 4.27$ & $308.6 \pm 5.01$ \\
Rutin & - & $8.9 \pm 0.47$ & $1.8 \pm 0.2$ \\
Myricetin & $3.2 \pm 0.21$ & $6.2 \pm 0.1$ & $14 \pm 0.32$ \\
Morin & $0.2 \pm 0.01$ & - & $0.6 \pm 0.01$ \\
Querecetin & - & $-509.2 \pm 4.21$ & - \\
Kaempherol & $552.2 \pm 9.21$ & - & $539 \pm 7.62$ \\
Catechin & $92.8 \pm 2.17$ & $2.5 \pm 0.11$ & $7.01 \pm 0.34$ \\
Naringenin & $2.2 \pm 0.01$ & & $10.8 \pm 0.37$ \\
Resveratrol & & $351.2 \pm 2.17$ & $396.8 \pm 4.1$ \\
Phenolic acid & & $0.6 \pm 0.1$ & $1.6 \pm 0.15$ \\
Vanilic acid & $382.1 \pm 3.41$ & $10.4 \pm 0.17$ & $153.2 \pm 2.13$ \\
Cinnamic acid & - & $1175 \pm 5.21$ & $19.2 \pm 0.97$ \\
Caffeic acid & $16.8 \pm 1.12$ & $989 \pm 4.92$ & $546.2 \pm 7.61$ \\
Ferulic acid & $1740.2 \pm 4.82$ & & \\
Rosmarinic acid & $1480 \pm 7.57$ & & \\
\hline
\end{tabular}

*By High pressure liquid chromatography. 
Furthermore, this study demonstrated that Salvia taxa had high DPPH and ABTS radical scavenging activities (Figures 1 and 2). Tepe et al. (2006) indicated that $S$. euphratica var. euphratica had more active plants based on the DPPH radical scavenging activity. Similarly, Senol et al. (2010) found that methanol extracts of Salvia taxa including S. euphratica var. leiocalycina (89.02 $\pm 0.80 \%-91.28 \pm 0.44 \%)$ and S. euphratica var. euphratica (88.85 $\pm 0.22 \%-92.39 \pm$ $0.22 \%$ ) had high DPPH radical scavenging capacity. Also, Senol et al. (2010) indicated that the ferrous ion chelating activity of S. euphratica var. leiocalycina $(23.23 \pm 0.84 \%)$ and S. euphratica var. euphratica $(12.9 \pm 1.32 \%)$ were higher than the present results. Furthermore, Yumrutas et al. (2012) showed that the DPPH radical scavenging capacity of $S$. euphratica var. leiocalycina was higher than in $S$. euphratica var. euphratica. The literatures reported that phenolic compounds were responsible for the antioxidant capacities in Lamiaceae including Salvia (Tosun et al., 2009; Roby et al., 2013; Kocak et al., 2016).

This study demonstrated that $S$. euphratica var. leiocalycina and S. euphratica var. euphratica had high metal chelating activity ( $82.22 \pm 1.29 \%-84.4 \pm 1.1 \%$, respectively)

\section{DPPH \%}

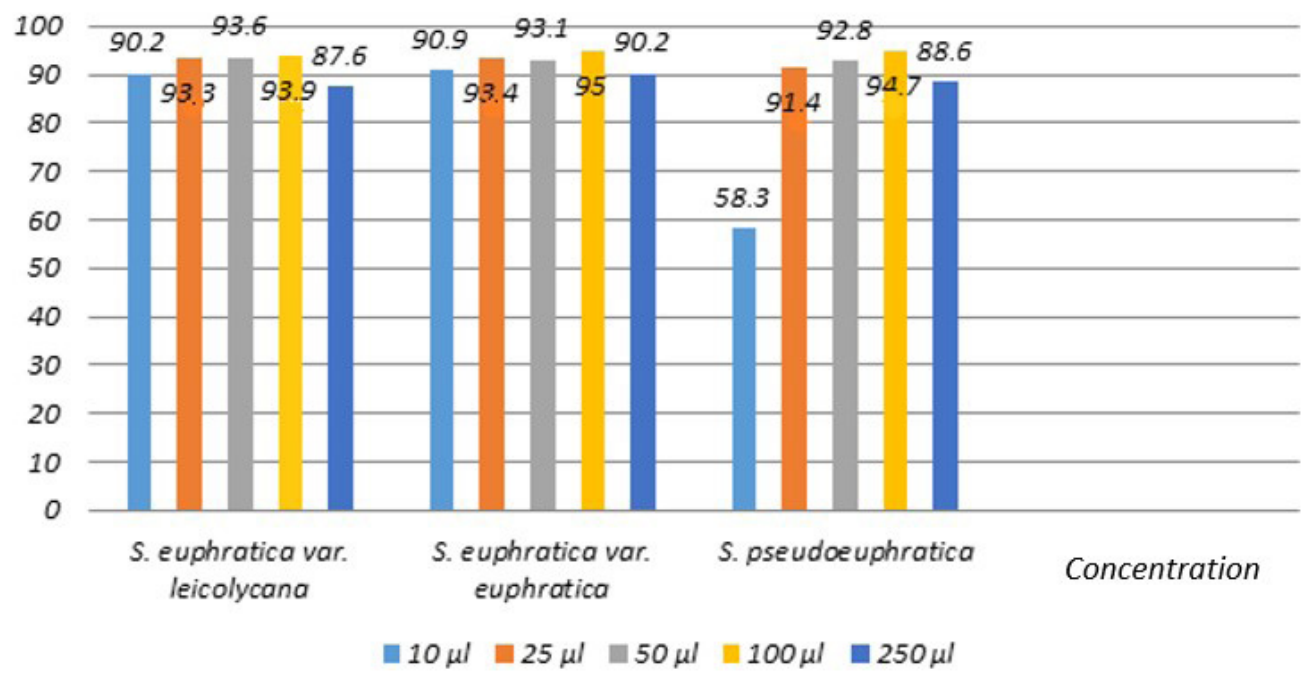

Figure 1. DPPH \% Radical Scavenging Activities of three Salvia taxa.

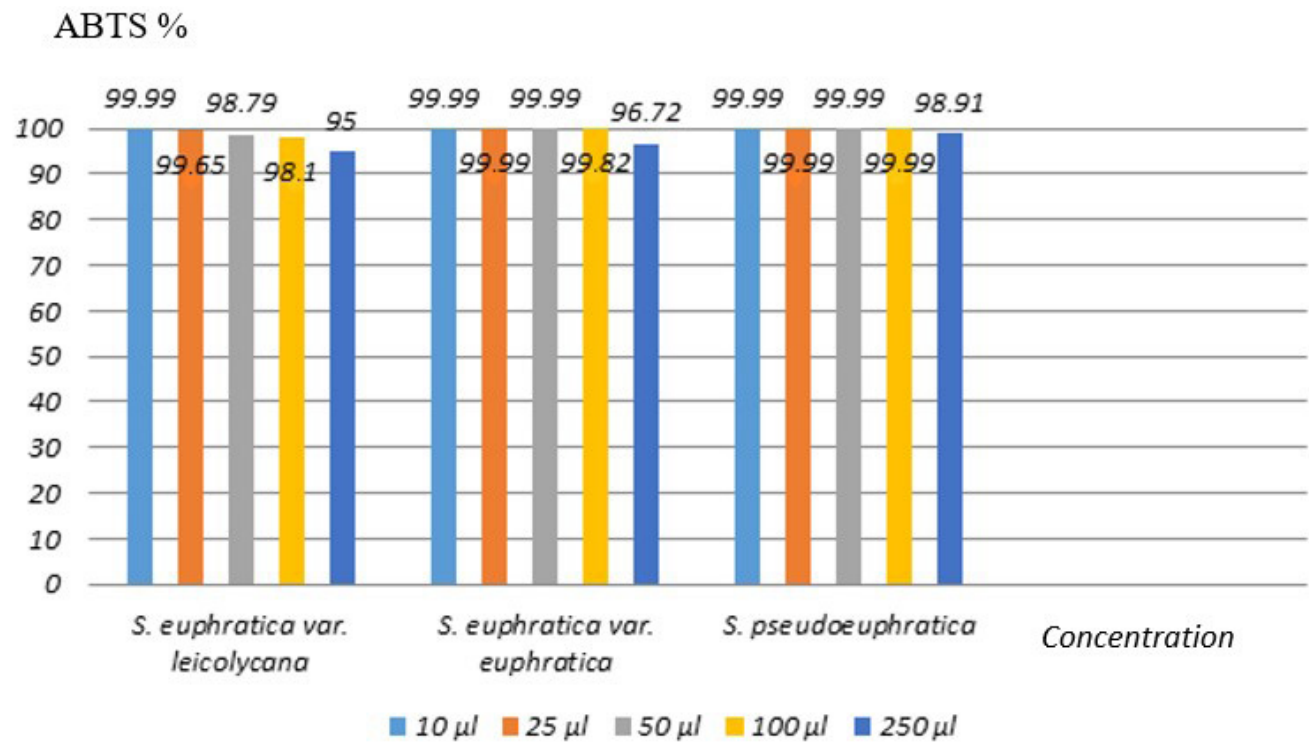

Figure 2. ABTS \% Radical Scavenging Activities of three Salvia taxa. 
while it was found that S. pseudoeuphratica had low metal chelating activity (30.33 $\pm 0.39 \%)$. Some studies reported that Salvia taxa comprising of S. euphratica var. leiocalycina had strong metal chelating capacity (Topcu et al., 2007; Zengin et al., 2018). In contrast, a study done by Senol et al. (2010) suggested that S. euphratica var. euphratica, and S. euphratica var. leiocalycina had low metal chelating activity. Additionally, it was observed that lipid peroxidation inhibitions of S. euphratica var. leiocalycina $(2.1 \pm 0.1 \mathrm{mg} /$ $\mathrm{kg})$ and S. euphratica var. euphratica ((3.47 $\pm 0.2 \mathrm{mg} / \mathrm{kg})$ are quite similar. But the lipid peroxidation inhibition of S. pseudoeuphratica calculated as $15.32 \pm 0.41 \mathrm{mg} / \mathrm{kg}$ lipid peroxidation. Sari et al. (2012) found that lipid peroxidation inhibition of Salvia taxa was between $0.58 \mathrm{mg} / \mathrm{l}$ and $0.92 \mathrm{mg} / \mathrm{l}$. Also, Khlifi et al. (2006) indicated that Salvia had significant inhibition of oxygen consumption. Furthermore, Giamperi et al. (2012) suggested that Salvia taxa had significant antioxidant activity against lipid peroxidation.

Furthermore, it was demonstrated that the biochemical results in the current study supported the morphological studies. In the flora of Turkey, S. pseudoeuphratica formerly has taken its place as a synonym of $S$. euphratica var. euphratica (Hedge, 1982a, b). However, it was shown that S. pseudoeuphratica apparently diverged from S. euphratica according to its many morphological characters, and it was demonstrated that former was clustered differently from latter in the dendrogram (Kahraman et al., 2010). In particular, it was found that some biochemical parameters (such as palmitic acid, linoleic acid, $\alpha$-linolenic acid, 18:3/18:2, rutin, naringenin, caffeic acid, ferulic acid and metal chelating) of S. pseudoeuphratica were different from the those of S. euphratica var. euphratica in the present study. Moreover, Kahraman et al. (2010) found that the populations of $S$. euphratica var. euphratica was clustered in a different position than the populations of $S$. euphratica var. leiocalycina in the dendrogram constructed using morphological characters. Also, Yilmaz et al. (2019) indicated that two varieties of S. euphratica had difference hair cover on the stem, bracts, calyx and pedicel, and Bagherpour (2010) reported that they had differences in glabrous inflorescence, the bracts, and the calyx. Similarly, it was reported that the current biochemical results (palmitic acid, oleic acid, linoleic acid, $\alpha$-linolenic acid, $\gamma$-linolenic acid, 18:3/18:2, U/S, $\alpha$-tocopherol, rutin, quercetin, naringenin, resveratrol, vanillic acid, caffeic acid, ferulic acid, and rosmarinic acid) of both variety were different from each other in the current study. Although it was stated that the difference in biochemical content is due to environmental conditions, soil structure, variation in sunlight hour, altitude, temperature and exposure to UV-B (Çetinkaya et al., 2017; Çoklar, 2017), the difference in the biochemical content of these two varieties was thought to be caused not only by environmental conditions but also by genetic differences.

\section{Conclusion}

The current study showed that palmitic acid was found as a major saturated fatty acid, and S. euphratica var. euphratica had lower palmitic acid ( $8.94 \pm 0.71 \%)$ and total saturated fatty acid (19.16 $\pm 0.15 \%)$ content than the two studied taxa. In addition, S. euphratica var. euphratica had the highest unsaturated fatty acid content (82.08 $\pm 0.52 \%$ ), and oleic acid, linoleic acid, $\alpha$-linolenic acid, and erucic acid were found as major unsaturated fatty acids. Furthermore, it was found that $18.3 / 18: 2$ (0.36) and the unsaturated/saturated fatty acid (4.28) ratios of S. euphratica var. euphratica were different from the two other studied taxa. It can be concluded that the fatty acids could be used as systematical tool, and the fatty acid content of S. euphratica var. euphratica diverged from the other two taxa. However, this study demonstrated that Salvia taxa had low lipid soluble vitamins and sterol contents. On the other hand, the present study demonstrated that the three studied Salvia taxa were found to have similar catechin $(509.2 \pm 4.21 \mu \mathrm{g} / \mathrm{g}$ and $552.2 \pm 9.21 \mu \mathrm{g} / \mathrm{g})$ and vanillic acid amounts (351.2 $\pm 2.17 \mu \mathrm{g} / \mathrm{g}$ and $396.8 \pm 4.1 \mu \mathrm{g} / \mathrm{g})$. Also, the studied Salvia taxa had high rosmarinic acid content; in particular, S. euphratica var. leiocalycina had the highest level of rosmarinic acid $(1480 \pm 7.57 \mu \mathrm{g} / \mathrm{g})$. On the other hand, two S. euphratica varieties had the highest ferulic acid content (1175 $\pm 5.21 \mu \mathrm{g} / \mathrm{mg}-1740.2 \pm 4.82 \mu \mathrm{g} / \mathrm{mg})$ while it was found the ferulic acid content of $S$. pseudoeuphratica was the lowest $(19.2 \pm 0.97 \mu \mathrm{g} / \mathrm{mg}$ ). Moreover, this study showed that Salvia taxa have a potent antioxidant capacity, and it was shown that the biochemical results were supported in the morphological studies.

\section{Acknowledgements}

Authors are grateful to Prof. Okkes Yilmaz for assistance in the reading on the HPLC and GC-MS devices.

\section{References}

ADIMCILAR, V., KALAYCIOGLU, Z., AYDOGDU, N., DIRMENCI, T., KAHRAMAN, A. and ERIM, F.B., 2019. Rosmarinic and carnosic acid contents and correlate antioxidant and antidiabetic activities of 14 Salvia species from Anatolia. Journal of Pharmaceutical and Biomedical Analysis, vol. 175, 112763. http:// dx.doi.org/10.1016/j.jpba.2019.07.011. PMid:31330278.

AKBULUT, S. and BAYRAMOGLU, M.M., 2013. The trade and use of some medical and aromatic herbs in Turkey. Studies on EthnoMedicine, vol. 7, no. 2, pp. 67-77. http://dx.doi.org/10.1080/09 735070.2013.11886446.

ALIPOUR-GOUGH, S. and ASGARPANAH, J., 2015. Essential and fixed oil chemical compositions of the seeds from the endemic species Salvia sharifii Rech. F. \& Esfand. Journal of the Chilean Chemical Society, vol. 60, pp. 4. http://dx.doi.org/10.4067/ S0717-97072015000400012.

ASADI, S., AHMADIANI, A., ESMAEILI, M.A., SONBOLI, A., ANSARI, N. and KHODAGHOLI, F., 2010. In vitro antioxidant activities and an investigation of neuroprotection by six Salvia species from Iran: a comparative study. Food and Chemical Toxicology, vol. 48, no. 5, pp. 1341-1349. http://dx.doi.org/10.1016/j. fct.2010.02.035. PMid:20197079.

AZCAN, N., ERTAN, A., DEMIRCI, B. and BASER, K.H.C., 2004. Fatty acid composition of seed oils of twelve Salvia species growing in Turkey. Chemistry of Natural Compounds, vol. 40, no. 3, pp. 218221. http://dx.doi.org/10.1023/B:CONC.0000039127.56323.3e. 
BAE, J., KIM, N., SHIN, Y., KIM, S.-Y. and KIM, Y.-J., 2020. Activity of catechins and their applications. Biomedical Dermatology, vol. 4, no. 8, pp. 1-10. http://dx.doi.org/10.1186/s41702-020-0057-8.

BAGCI, E., VURAL, M., DIRMENCI, T., BRUEHL, L. and AITZETMÜLLERD, K., 2004. Fatty acid and tocochromanol patterns of some Salvia L. species. Zeitschrift für Naturforschung, vol. 59c, no. 5-6, pp. 305-309. http://dx.doi.org/10.1515/znc-2004-5-601. PMid: 18998390

BAGHERPOUR, S., 2010. Taxonomic studies on the genus Salvia L. (Labiatae) in central Anatolia, Turkey. Turkey: Graduate School of Natural and Applied Sciences, Middle East Technical University. PhD Thesis in Philosophy Science.

BAHSI, M., 2008. The effects of resveratrol and $\alpha$-lipic acid on some biochemical parameters in tissue and plasma of aged rats induced by 7,12-DMBA. Elazı ğ: Graduate School of Natural and Applied Sciences. PhD Thesis in Biology.

BAKOGLU, A., KILIC, O. and KOKTEN, K., 2016. Fatty acid composition of the leaves of some Salvia taxa from Turkey. Chemistry of Natural Compounds, vol. 528, no. 4, pp. 676-678. http://dx.doi. org/10.1007/s10600-016-1738-9.

BARDAKCI, H., CELEP, E., GÖZET, T., KURT-CELEP, I., DENIZ, I., ŞEN-UTSUKARCI, B. and AKAYDIN, G., 2019. A comparative investigation on phenolic composition, antioxidant and antimicrobial potentials of Salvia heldreichiana Boiss. ex Bentham extracts. South African Journal of Botany, vol. 125, pp. 72-80. http://dx.doi.org/10.1016/j.sajb.2019.07.010.

BEN FARHAT, M., JORDAN, M.J., CHAOUCH-HAMADA, R., LANDOULSI, A. and SOTOMAYOR, J.A., 2015a. Changes in phenolic profiling and antioxidant capacity of Salvia aegyptiaca L. by-products during three phenological stages. Lebensmittel-Wissenschaft + Technologie, vol. 63, no. 1, pp. 791-797. http://dx.doi. org/10.1016/j.lwt.2015.03.015

BEN FARHAT, M., HAMADA, R.C. and LANDOULSI, A., 2015b. Oil yield and fatty acid profile of seeds of three Salvia species: a comparative study. Herba Polonica, vol. 61, no. 2, pp. 14-29. http://dx.doi.org/10.1515/hepo-2015-0012.

BENTHAM, G., 1836. Salvia. Annales des Sciences Naturelles; Botanique, vol. 2, p. 40.

CELEP, F., DIRMENCI, T. and GUNER, O., 2015. Salvia hasankeyfense (Lamiaceae), a new species from Hasankeyf (Batman, Southeastern Turkey). Phytotaxa, vol. 227, no. 3, pp. 289-294. http:// dx.doi.org/10.11646/phytotaxa.227.3.9.

CETINKAYA, H., KULAK, M., OZKAN, A., CELIK, M.A. and SEKEROGLU, N., 2017. Influence of geographical factors on the fatty acid profile and oil yield of Olea europaea L. Scientific Papers. Series. Agronomy, vol. LX, pp. 468-474.

CHRISTIE, W.W., 1990. Gas chromatography and lipids. Glaskow: The Oily Press, pp. 573-577.

COKLAR, H., 2017. Antioxidant capacity and phenolic profile of berry, seed, and skin of Ekşikara (Vitis vinifera L) grape: influence of harvest year and altitude. International Journal of Food Properties, vol. 20, no. 9, pp. 2071-2087. http://dx.doi.or g/10.1080/10942912.2016.1230870

DANDEKAR, P. and WASEWAR, K.L., 2020. Experimental investigation on extractive separation of vanillic acid. Chemical Data Collections, vol. 30, 100564. https://doi.org/10.1016/j. cdc.2020.100564.

DELANGE, D.M., RICO, C.L.M., GONZALES CANAVACIOLO, V.L., PÉREZ, R.S. and LEYES, E.A.R., 2012. Fatty acid composition of seed oil from Salvia coccinea grown in Cuba. Analytical Chemistry Letters, vol. 2, no. 2, pp. 114-117. http://dx.doi.org/10.1080/22 2979282000.10648257.
DINIS, T.C.P., MADEIRA, V.M.C. and ALMEIDA, L.M., 1994. Action of phenolic derivatives (acetaminophen, salicylate, and 5-aminosalicylate) as inhibitors of membrane lipid peroxidation and as peroxyl radical scavengers. Archives of Biochemistry and Biophysics, vol.315, no. 1, pp. 161-169. http://dx.doi.org/10.1006/ abbi.1994.1485. PMid:7979394.

DIZKIRICI, A., CELEP, F., KANSU, C., KAHRAMAN, A., DOGAN, M. and KAYA, Z., 2015. A molecular phylogeny of Salvia euphratica sensu lato (Salvia L., Lamiaceae) and its closely related species with a focus on the section Hymenosphace. Plant Systematics and Evolution, vol. 301, no. 10, pp. 2313-2323. http://dx.doi. org/10.1007/s00606-015-1230-1.

EL EUCH, S.K., HASSINE, D.B., CAZAUX, S., BOUZOUITA, N. and BOUAJILA, J., 2019. Salvia officinalis essential oil: chemical analysis and evaluation of antienzymatic and antioxidant bioactivities. South African Journal of Botany, vol. 120, pp. 253260. http://dx.doi.org/10.1016/j.sajb.2018.07.010.

ERDOGAN-ORHAN, I., SEZER-SENOL, F., OZTURK, N., AKAYDIN, G. and SENER, B., 2012. Profiling of in vitro neurobiological effects and phenolic acids of selected endemic Salvia species. Food Chemistry, vol. 132, no. 3, pp. 1360-1367. http://dx.doi. org/10.1016/j.foodchem.2011.11.119. PMid:29243623.

GEZEK, G., HASHEMI, P., KALAYCIOGLU, Z., KAYGUSUZ, H., SARIOGLU, G., DOKER, S., DIRMENCI, T. and ERIM, F.B., 2019. Evaluation of some Turkish Salvia species by principal component analysis based on their vitamin B2, mineral composition, and antioxidant properties. Lebensmittel-Wissenschaft + Technologie, vol. 100, pp. 287-293. http://dx.doi.org/10.1016/j.lwt.2018.10.066.

GIAMPERI, L., BUCCHINI, A., BISIO, A., GIACOMELLI, E., ROMUSSI, G. and RICCI, D., 2012. Total phenolic content and antioxidant activity of Salvia spp. exudates. Natural Product Communications, vol. 7, no. 2, pp. 201-202. http://dx.doi. org/10.1177/1934578X1200700221. PMid:22474957.

GOREN, A.C., KILIC, T., DIRMENCI, T. and BILSEL, G., 2006. Chemotaxonomic evaluation of Turkish species of Salvia: fatty acid compositions of seed oils. Biochemical Systematics and Ecology, vol. 34, no. 2, pp. 160-164. http://dx.doi.org/10.1016/j. bse.2005.09.002.

HABIBVASH, F.N., RAJAMAND, M.A., HEIDARI, R., SARGHEIN, S.H. and RICANI, M.H., 2007. Chemical analysis of some Salvia species native to west Azarbaijan. Pakistan Journal of Botany, vol. 10, no. 20, pp. 3516-3524. http://dx.doi.org/10.3923/ pjbs.2007.3516.3524. PMid:19093457.

HARA, A. and RADIN, N.S., 1978. Lipid extraction of tissues with a low-toxicity solvent. Analytical Biochemistry, vol. 90, no. 1, pp. 420-426. http://dx.doi.org/10.1016/0003-2697(78)90046-5. PMid:727482.

HEDGE, I.C., 1982a. Salvia. In: P.H. DAVIS, ed. Flora of Turkey and the East Aegean Islands: Salvia L. Edinburgh: University of Edinburgh Press, vol. 7.

HEDGE, I.C., 1982b. Labiatae. In: K.H. RECHINGER, ed. Flora Iranica: Salvia L. Graz: Akademische Druck und Verlagsanstalt, vol. 150, pp. 403-404.

HOSSAIN, M.B., BARRY-RYAN, C., MARTIN-DIANA, A.B. and BRUNTON, N.P., 2010. Effect of drying method on the antioxidant capacity of six Lamiaceae herbs M.B. Food Chemistry, vol. 123, no. 1, pp. 85-91. http://dx.doi.org/10.1016/j.foodchem.2010.04.003.

ISEMURA, M., 2019. Catechin in human health and disease. Molecules, vol. 24, no. 3, pp. 528. http://dx.doi.org/10.3390/ molecules24030528.

KAHRAMAN, A., CELEP, F., DOGAN, M. and BAGHERPOUR, S., 2010. A taxonomic revision of Salvia euphratica sensu lato and its closely related species (sect. Hymenosphace, Lamiaceae) by 
using multivariate analysis. Turkish Journal of Botany, vol. 34, pp. 261-276. http://dx.doi.org/10.3906/bot-0910-194.

KALAYCIOĞLU, Z., UZAŞÇI, S., DIRMENCI, T. and ERIM, F.B., 2018. $\alpha$-Glucosidase enzyme inhibitory ef-fects and ursolic and oleanolic acid contents of fourteen Anatolian Salvia species. Journal of Pharmaceutical and Biomedical Analysis, vol. 155, pp. 284-287. http://dx.doi.org/10.1016/j.jpba.2018.04.014. PMid:29677678.

KELEN, M. and TEPE, B., 2008. Chemical composition, antioxidant and antimicrobial properties of the essential oils of three Salvia species from Turkish flora. Bioresource Technology, vol. 99, no. 10, pp. 4096-4104. http://dx.doi.org/10.1016/j.biortech.2007.09.002. PMid:17936619.

KESER, S., DEMIR, E. and YILMAZ, O., 2014. Phytochemicals and antioxidant activity of the almond kernel (Prunus dulcis Mill.) from Turkey. Journal of the Chemical Society of Pakistan, vol. 36, no. 3, pp. 534-541.

KHLED KHOUDJA, N., BOULEKBACHE-MAKHLOUF, L. and MADANI, K., 2014. Antioxidant capacity of crude extracts and their solvent fractions of selected Algerian Lamiaceae. Industrial Crops and Products, vol. 52, pp. 177-182. http://dx.doi.org/10.1016/j. indcrop.2013.10.004.

KHLIFI, S., EL HACHIMI, Y., KHALIL, A., ES-SAFI, N., BELAHYAN, A., TELLAL, R. and EL ABBOUYI, A., 2006. In vitro antioxidant properties of Salvia verbenaca $L$. hydromethanolic extract. Indian Journal of Pharmacology, vol. 38, no. 4, pp. 276-280. http://dx.doi.org/10.4103/0253-7613.27025.

KILIC, O., 2018. Essential oil and fatty acid composition of leaves of some Lamiaceae taxa from Turkey. TEOP, vol. 21, no. 6, pp. 1706-1711. http://dx.doi.org/10.1080/0972060X.2018.1538820.

KILIC, T., DIRMENCI, T., SATIL, F., BILSEL, G., KOCAGOZ, T., ALTUN, M. and GOREN, A.C., 2005. Fatty acid compositions of seed oils of three Turkish Salvia species and biological activities. Chemistry of Natural Compounds, vol. 41, no. 3, pp. 276-279. http://dx.doi.org/10.1007/s10600-005-0128-5.

KIVRAK, S., GOKTURK, T., KIVRAK, I., KAYA, E. and KARABABA, E., 2019. Investigation of phenolic profiles and antioxidant activities of some Salvia species commonly grown in southwest Anatolia using UPLC-ESI-MS/MS. Food Science and Technology, vol. 39, no. 2, pp. 423-431. http://dx.doi.org/10.1590/fst.32017.

KIZILPINAR-TEMIZER, I., GUDER, A. and GENCAY-CELEMLI, O., 2017. Botanical origin and antioxidant activities of propolis from the Irano-Turanian region. İstanbul Journal of Pharmacy, vol. 47, no. 3, pp. 107-111. http://dx.doi.org/10.5152/IstanbulJPharm.2017.0017.

KOCAK, M.S., SARIKURKCU, C., CENGIZ, M., KOCAK, S., UREN, M.C. and TEPE, B., 2016. Salvia cadmica: phenolic composition and biological activity. Industrial Crops and Products, vol. 85, pp. 204-212. http://dx.doi.org/10.1016/j.indcrop.2016.03.015.

KUMAR, N. and PRUTHI, V., 2014. Potential applications of ferulic acid from natural sources. Biotechnology Reports, vol. 4, pp. 86-93. http://dx.doi.org/10.1016/j.btre.2014.09.002. PMid:28626667.

KURŞAT, M., EMRE, I., YILMAZ, O. and ERECEVIT, P., 2011. Antioxidant and antimicrobial activity in the seeds of Origanum vulgare L. subsp. gracile (C. Koch) Ietswaart and Origanum acutidens (Hand.-Mazz.) Ietswaart from Turkey. Grasas y Aceites, vol. 62, no. 4, pp. 410-417. http://dx.doi.org/10.3989/gya.113610.

LIYANA-PATHIRANA, C.M. and SHAHIDI, F., 2005. Antioxidant activity of commercial soft and hard wheat (Triticum aestivum L.) as affected by gastric $\mathrm{pH}$ conditions. Journal of Agricultural and Food Chemistry, vol. 53, no. 7, pp. 2433-2440. http://dx.doi. org/10.1021/jf049320i. PMid:15796575.

LOIZZO, M.R., TUNDIS, R., CONFORTI, F., MENICHINI, F., BONESI, M., NADJAFI, F., FREGA, N.G. and MENICHINI, F., 2010. Salvia leriifolia Benth (Lamiaceae) extract demonstrates in vitro antioxidant properties and cholinesterase inhibitory activity. Nutrition Research, vol. 30, no. 12, pp. 823-830. http://dx.doi. org/10.1016/j.nutres.2010.09.016. PMid:21147365.

LÓPEZ-CERVANTES, J., SÁNCHEZ-MACHADO, D.I. and RIOS-VÁZQUEZ, J., 2006. High-performance liquid chromatography method for the simultaneous quantification of retinol, $\alpha$-tocopherol, and cholesterol in shrimp waste hydrolysate. Journal of Chromatography A, vol. 1105, no. 1-2, pp. 135-139. http://dx.doi. org/10.1016/j.chroma.2005.08.010. PMid:16439259.

LU, Y. and YEAP, F., 2002. Polyphenolics of Salvia: a review. Phytochemistry, vol. 59, no. 2, pp. 117-140. http://dx.doi. org/10.1016/S0031-9422(01)00415-0. PMid:11809447.

MOAZZAMI FARIDA, S.H., RADJABIAN, T., RANJBAR, M., SALAMI, S.A., RAHMANI, N. and GHORBANI, A., 2016. Fatty acid patterns of seeds of some Salvia species from Iran: a chemotaxonomic approach. Chemistry \& Biodiversity, vol. 13, no. 4, pp. 451-458. http://dx.doi.org/10.1002/cbdv.201500147. PMid:26988735.

NAGHIBI, F., MOSADEGH, M., MOTAMED, S.M. and GHORBANI, A., 2005. Labiatae Family in folk medicine in Iran: from Ethnobotany to Pharmacology. Iranian Journal of Pharmaceutical Research, vol. 2, pp. 63-79. http://dx.doi.org/10.22037/IJPR.2010.619.

NAJJAA, H., ABDELKARIM, B.A., DORIA, E., BUBAKRI, A., TRABELSI, N., FALLEH, H., TLILI, H. and NEFFATI, M., 2020. Phenolic composition of some Tunisian medicinal plants associated with anti-proliferative effect on human breast cancer MCF-7 cells. The Euro Biotech Journal, vol. 4, no. 2, pp. 104-112. http:// dx.doi.org/10.2478/ebtj-2020-0012.

RE, R., PELLEGRINI, N., PROTEGGENTE, A., PANNALA, A., YANG, M. and RICE-EVANS, C., 1999. Antioxidant active,ty applying an improved ABTS radical cation decolorization assay. Free Radical Biology \& Medicine, vol. 26, no. 9-10, pp. 1231-1237. http:// dx.doi.org/10.1016/S0891-5849(98)00315-3. PMid:10381194.

ROBY, M.H.H., SARHAN, M.A., SELIM, K.A.-H. and KHALEL, K.I., 2013. Evaluation of antioxidant activity, total phenols and phenolic compounds in thyme (Thymus vulgaris L.), sage (Salvia officinalis L.), and marjoram (Origanum majorana L.) extracts. Industrial Crops and Products, vol. 43, pp. 827-831. http://dx.doi. org/10.1016/j.indcrop.2012.08.029.

SÁNCHEZ-MACHADO, D., LÓPEZ-HERNÁNDEZ, J. and PASEIROLOSADA, P., 2002. High-performance liquid chromatographic determination of a-tocopherol in macroalgae. Journal of Chromatography A, vol. 976, no. 1, pp. 277-284. http://dx.doi. org/10.1016/S0021-9673(02)00934-2. PMid:12462619.

SARI, A., KURSAT, M., CIVELEK, S. and EMRE, I., 2009. Vitamin contents of some Salvia L. taxa growing in Turkey. Chemistry of Natural Compounds, vol. 45, no. 6, pp. 944-946. http://dx.doi. org/10.1007/s10600-010-9468-X.

SARI, A., KURSAT, M. and CIVELEK, S., 2012. Determination of MDA levels in the plant (some Salvia L. taxa growing in Turkey). Journal of Drug Metabolism E Toxicology, vol. 3, no. 3, pp. 117. http://dx.doi.org/10.4172/2157-7609.1000117.

SCHUCHARDTA, U., SERCHELIA, R. and VARGAS, R.M., 1998. Transesterification of vegetable oils: a Review. Journal of the Brazilian Chemical Society, vol. 9, no. 1, pp. 199-210. http:// dx.doi.org/10.1590/S0103-50531998000300002.

SENOL, F.S., ORHAN, I., CELEP, F., KAHRAMAN, A., DOGAN, M., YILMAZ, G. and SENER, B., 2010. Survey of 55 Turkish Salvia taxa for their acetylcholinesterase inhibitoryand antioxidant activities. Food Chemistry, vol. 120, no. 1, pp. 34-43. http:// dx.doi.org/10.1016/j.foodchem.2009.09.066.

SHARAFZADEH, S. and ZARE, M., 2011. Influence of growth regulators on growth and secondary metabolites of some medicinal plants 
from Lamiaceae Family. Advances in Environmental Biology, vol. 5, no. 8, pp. 2296-2302.

SHIMOI, K., MASUDA, S., FURUGORI, M., ESAKI, S. and KINAE, N., 1994. Radioprotective effect of antioxidative flavonoids in X-ray irradiated mice. Carcinogenesis, vol. 15, no. 11, pp. 2669-2672. http://dx.doi.org/10.1093/carcin/15.11.2669. PMid:7955124.

SKOTTI, E., ANASTASAKI, E., KANELLOU, G., POLISSIOU, M. and TARANTILIS, P.A., 2014. Total phenolic content, antioxidant activity and toxicity of aqueous extracts from selected Greek medicinal and aromatic plants. Industrial Crops and Products, vol. 53, pp. 46-54. http://dx.doi.org/10.1016/j.indcrop.2013.12.013.

ST-ONGE, M.-P. and FOO, L.Y., 2003. Phytosterols and human lipid metabolism: efficacy, safety, and novel foods. Lipids, vol. 38, no. 4, pp. 367-375. http://dx.doi.org/10.1007/s11745-003-1071-3. PMid:12848281.

TEPE, B., 2008. Antioxidant potentials and rosmarinic acid levels of the methanolic extracts of Salvia virgata (Jacq), Salvia staminea (Montbret \&Aucher ex Bentham) and Salvia verbenaca (L.) from Turkey. Bioresource Technology, vol. 99, no. 6, pp. 1584-1588. http://dx.doi.org/10.1016/j.biortech.2007.04.008. PMid:17531471.

TEPE, B., SOKMEN, M., AKPULAT, H.A. and SOKMEN, A., 2006. Screening of the antioxidant potentials of six Salvia species from Turkey. Food Chemistry, vol. 95, no. 2, pp. 200-204. http:// dx.doi.org/10.1016/j.foodchem.2004.12.031.

TOPCU, G., ERTAS, A., KOLAK, U., OZTURK, M. and ULUBELEN, A., 2007. Antioxidant activity tests on novel triterpenoids from Salvia macrochlamys. ARKIVOC, vol. 7, pp. 195-208. http://dx.doi. org/10.3998/ark.5550190.0008.716.

TOSUN, M., ERCISLI, S., SENGUL, M., OZER, H., POLAT, T. and OZTURK, E., 2009. Antioxidant properties and total phenolic content of eight Salvia species from Turkey. Biological Research, vol. 42, no. 2, pp. 175-181. http://dx.doi.org/10.4067/S071697602009000200005. PMid:19746262.

TRAUTWEIN, E.A. and DEMONTY, I., 2007. Phytosterols: natural compounds with established and emerging health benefits.
Oilseeds and Fats, Crops and Lipids, vol. 14, no. 5, pp. 259-266. http://dx.doi.org/10.1051/ocl.2007.0145.

TUNGMUNNITHUM, D., THONGBOONYOU, A., PHOLBOON, A. and YANGSABAI, A., 2018. Flavonoids and other phenolic compounds from medicinal plants for pharmaceutical and medical aspects: an overview. Medicines, vol. 5, no. 3, pp. 93. http://dx.doi. org/10.3390/medicines5030093. PMid:30149600.

TURAN, H., ERKOYUNCU, I. and KOCATEPE, D., 2013. Omega-6, omega-3, fatty acids and Fish. Yunus Research Bulletin, vol. 2, pp. 45-50.

YILMAZ, H., BAĞCI, E., DOĞAN, G. and KILIÇ, Ö., 2019. A numerical taxonomic study on some Salvia L. (Lamiaceae) taxa from Turkey. Asian Journal of Science and Technology, vol. 10, no. 02, pp. 9425-9430.

YUMRUTAS, O., SOKMEN, A., AKPULAT, H.A., OZTURK, N., DAFERERA, D., SOKMEN, M. and TEPE, B., 2012. Phenolic acid contents, essential oil compositions and antioxidant activities of two varieties of Salvia euphratica from Turkey. Natural Product Research, vol. 26, no. 19, pp. 1848-1851. http://dx.doi.org/10.1 080/14786419.2011.613386. PMid:21995274.

ZENGIN, G., LLORENT-MARTINEZ, E., FERNANDEZ-DE CÓRDOVA, M.L., BAHADORI, M.B., MOCAN, A., LOCATELLI, M. and AKTUMSEK, A., 2018. Chemical composition and biological activities of extracts from three Salvia species: S. blepharochlaena, S. euphratica var. leiocalycina, and S. verticillata subsp. amasiaca. Industrial Crops and Products, vol. 111, pp. 11-21. http://dx.doi.org/10.1016/j. indcrop.2017.09.065.

ZU, Y.G., LI, C.Y., FU, Y.J. and ZHAO, C.J., 2006. Simultaneous determination of catechin, rutin, quercetin kaempherol and isorhamnetin in the extract of sea buckthorn (Hippophae rhamnoides L.) leaves by RP-HPLC with DAD. Journal of Pharmaceutical and Biomedical Analysis, vol. 41, no. 3, pp. 714-719. http://dx.doi.org/10.1016/j.jpba.2005.04.052. PMid:16520013. 